\title{
The Effectiveness of Instructional Media to Improve Early Childhood Creative Thinking Skills
}

\author{
Margarita Inuk ${ }^{1}$, Erdawati $^{1}$, Tjipto Sumadi ${ }^{1}$, Jarudin $^{2, *}$ \\ ${ }^{1}$ Early Childhood Education Programs, State University of Jakarta, DKI Jakarta, 132220, Indonesia \\ ${ }^{2}$ Department of Technology Information, STMIK Bina Sarana Global, Banten, 15114, Indonesia
}

Received November 14, 2020; Revised April 15, 2021; Accepted May 11, 2021

\begin{abstract}
Cite This Paper in the following Citation Styles
(a): [1] Margarita Inuk, Erdawati, Tjipto Sumadi, Jarudin, "The Effectiveness of Instructional Media to Improve Early Childhood Creative Thinking Skills," Universal Journal of Educational Research, Vol. 9, No. 6, pp. 1291-1297, 2021. DOI: 10.13189/ujer.2021.090618.
\end{abstract}

(b): Margarita Inuk, Erdawati, Tjipto Sumadi, Jarudin (2021). The Effectiveness of Instructional Media to Improve Early Childhood Creative Thinking Skills. Universal Journal of Educational Research, 9(6), 1291-1297. DOI: $10.13189 /$ ujer.2021.090618.

Copyright $\odot 2021$ by authors, all rights reserved. Authors agree that this article remains permanently open access under the terms of the Creative Commons Attribution License 4.0 International License

\begin{abstract}
Instructional media is a tool used in the learning process to convey material, information and communicate with students to achieve learning effectiveness. The use of instructional media is also expected to increase students' understanding of the subjects being taught. This study aims to develop instructional media in improving creative thinking skills in early childhood ages $5-6$ years. The number of samples in this study was 36 divided into three groups. The first group consisted of three students with different characteristics for the implementation of the one-to-one trial. The second group consists of 6 students for the small group trial. At the same time, the third group consisted of 25 students for field trials. The instruments used were pre-test and post-test. The stages of developing instructional media are carried out in three main stages, namely; 1) conduct needs analysis, 2) develop initial products, 3) expert validation, revisions, and trials. The results showed that effective instructional media could improve early childhood creative thinking skills. For that, it is suggested that teachers become learning developers, not just educators. Therefore an understanding of development research is needed to support the learning process. Implications Educational institutions can take advantage of learning media that have been developed because of the obstacles that students have faced in increasing their creative thinking skills.
\end{abstract}

Keywords Media Effectiveness, Early Childhood, Creative Thinking

\section{Introduction}

Memorization and non-contextual learning makes children less understanding of deep learning. Children have difficulty understanding more complex ideas and applying the knowledge they acquire to new situations. As a result, children cannot build knowledge and apply their learning from one case to another. Learning like this makes children who are only mental followers and not innovators, less initiative, who must always be directed, passive and less dynamic. Learning outcomes that still emphasize academic skills using repetition and memorization are still found in some developing countries[1]. Parents' mistaken believe that a child's academic success is $100 \%$ in the school's hands. Parents' pride lies when the child gets an excellent academic achievement, the education program is still teacher-centred rather than child-centred[2]. Learning that frees the child to reflect his interests, develop creativity is far from hopeful.

Children's creative abilities where children can have the ability to develop their ideas are less developed. This results in the profile of graduates not being met. To improve creative skills in early childhood[3]. Kindergarten education should provide a pleasant, meaningful, and warm experience, as parents provide in a home environment[4]. In line with this, it was revealed that early childhood education is intended to facilitate the growth of 
children based on the norms and values of life[5]. Early childhood education should not be academically oriented but should provide a learning experience for the child. Early childhood education programs must also be tailored to the needs, interests, and development of children.

Based on the mapping of previous research that relevant that textbooks are excellent to increase student creativity[6]. Instructional strategies using questions, class discussions, self-directed studies, inductive and deductive thinking, media or social media make students engage in learning activities and create learning innovations[7]. Media as a practical guide on how thinking skills can be improved in the classroom of the early years and how to assess whether young people think constructively[8]. Innovation and creativity are fundamental to all academic disciplines and educational activities. The creative process and the reflections considered are critical components to understanding the learning experience. Several teaching and learning approaches need to be considered in helping nurture creativity and innovation[9].

The confidence of the teachers doesn't seem to have changed much throughout the entire project period. However, the practice of constructive pedagogy of thought strategy interventions appears to affect teachers' teaching of more dialogist methods[10]. Creativity is an essential human characteristic. This is probably the best thought as a process, requiring a mixture of ingredients, including personality traits, abilities and skills, in helping young people to develop their creativity by providing a creative environment, allowing children to build skills through playing, behaving creatively themselves and praising children's creative efforts[11].

Based on previous research results, a new focus to increase creativity in upper-level students is not yet in early childhood. Meanwhile, Sharp research has focused on developing a learning environment to increase children's imagination, but not yet with media instruction. Researchers will develop media instruction to improve the creative thinking of early childhood aged 5-6years. Learning media is a material presence that teachers can use to carry out teaching and learning activities and support students in achieving learning objectives[12], [13]. It shows that teaching media includes all materials and physical means that teachers can use to carry out learning and facilitate students' learning objectives. In this study, learning media is interpreted as a tool used in the learning process to convey materials, information and communicate with students to achieve learning effectiveness.

Teachers should help early childhood discover their talents and appreciate them. To develop creative thinking, children need to be left creatively busy. Educators should stimulate early childhood to engage in activities by helping to find what is required. In this case, the important thing is to give the child the freedom to express themselves creatively because it does not harm others or the environment[14]. First of all, all that is required is the process of busying yourself creatively without having to always or too quickly demand; it will come naturally in a climate of support, acceptance, and appreciation.

The purpose of this research is to develop instructional media to improve early childhood creative thinking skills. The question of his study is whether is it practical to enhance creative thinking skills in early childhood? The novelty of this research on the concept of media dislocation through Investigation, idea generation, implementation, communication and evaluation.

\section{Materials and Methods}

\subsection{Sample}

The research was conducted in four places, namely Study Group B Penabur Jakarta and Bekasi. It involves 36 students range from 5 to 6 years old divided into three groups. The first group consisted of 3 participants with moderate ability characteristics, above medium and below average for the One-to-one trial. The second group consisted of 6 participants for a small group trial with the same characteristics as the On-to-one trial. The third group consisted of 25 participants used for field tests as the effectiveness of the developed product.

\subsection{Research Design}

The approach used in this study is a quantitative approach by obsessing over the Hannafin and Peck models[15]. The process after the instruction media has been developed before the trial with prospective users will be validated. Validation is carried out by a team of experts consisting of content, design and media experts. After the media is declared viable by a team of experts, the developed product is conducted with one-to-one groups, small groups, and large groups.

\subsection{Research Instruments}

Instruments are designed according to the concept of creative thinking skills to determine the level of understanding after completing a series of learnings. The device used is a Likert-scale questionnaire intended to assess the level of knowledge based on creative thinking abilities. The assessment rubric for score: $1=$ children are not developing, $2=$ children are designing, $3=$ children are developing as expected, and $4=$ children are developing very well. The instrument used has been validated before use. The question item consists of 6 items. The grid of items used is presented in Table 1. The component discussed in this study is creative thinking skills. 
Table 1. Creative Thinking Instrument Grid

\begin{tabular}{|c|c|c|}
\hline No. & Question indicator & $\begin{array}{c}\text { Number of } \\
\text { items }\end{array}$ \\
\hline 1. & Delivering Ideas & 1 \\
2. & Combine ideas & 1 \\
3. & Troubleshooting & 1 \\
4. & Alternative answers & 1 \\
5. & Correct & 1 \\
6. & Find a function & 1 \\
\hline & Total & 6 \\
\hline
\end{tabular}

\subsection{Data Analysis Techniques}

Data analysis techniques with quantitative approaches are carried out by conducting statistical tests to determine the significance of differences in children's abilities before and after the learning media trials. According to Borg, Gall and Gall[16], for respondents less than 30, statistical tests are conducted by conducting t-tests. T-test was conducted to determine the effectiveness of media instruction on implementing large group trials-T-test for paired or non-independent samples, using the t-test formula[17]. T-test was conducted to determine the effectiveness of media instruction on the implementation of large group trials. The t-count value is then compared to the one-way test tablet-value with a confidence level of $\alpha=95 \%$ with a freedom level $(\mathrm{df}=\mathrm{n}-1)$. If the $\mathrm{t}$-count is greater than the $\mathrm{t}$-table, then the researcher rejects the zero hypotheses, which means the alternative hypothesis is accepted

\section{Results and Discussion}

This study results produce innovative instructional media that can improve creative thinking in early childhood ages 5-6 years. By using instructional media that are designed systematically, early childhood can improve their creative thinking skills. Instructional media has been validated based on an expert team's assessment consisting of content, media, and design experts.

\subsection{One-to-One Trial Results}

The results of the One-to-one trial were carried out between learning developers and three students individually. The selected students are students who have moderate, above moderate, and under-moderate abilities. This trial aims to identify and reduce errors in instructional media; besides, this evaluation is intended to get students responses about the content of instructional media, materials, and the feasibility of instructional media empirically. The developer provides each student with learning media and response sheets to freely provide information and instructional media responses. The provision of instructional media and response sheets is carried out separately to make responses according to their individual opinions. This One to one test concludes the results of the answers given to improve overall learning activities.

At the end of the one-to-one trial, a test will be given to measure the level of understanding of the learning material being studied, while the test results data for three students are presented in table 2 .

Table 2. Results of one to one trial

\begin{tabular}{|c|c|c|}
\hline No. & Respondent & Ability to think creatively \\
\hline 1. & Respondent 01 & Children develop very well \\
\hline 2. & Respondent 02 & Children develop as expected \\
\hline 3. & Respondent 03 & Children develop very well \\
\hline
\end{tabular}

Based on the results of one-to-one trials that children develop as expected and develop very well, the learning media created is very feasible for learning.

\subsection{Small Group Trial Results}

Small group evaluation aims to obtain information used in improving the product in the next revision. The trial phase was carried out on six students. This small group represents the actual target population, and among them does not include students who have participated in the One-to-one trial. The input expected is not only about instructional media but also the instructional process.

This stage begins by gathering students in the classroom and then being informed about the intent and purpose of conducting the small group trial. The information conveyed is in the form of responses from students to the activities that take place including assessing the quality of learning products both regarding the material and the learning process and tests that will be carried out at the end of this trial. The distribution of instructional media and comment sheets to students is carried out after being informed of the trial's objectives and intentions. Then give students one month to study the instructional media and fill out the comment sheets that have been distributed.

Most students have no difficulty understanding the material in the instructional media from the small group evaluation results. Students generally comment very clearly for instructional purposes because each content explains and illustrates images and examples that support understanding. Table 3 questions and comments from students as follows. 
Table 3. Results students' comments during the trial

\begin{tabular}{|c|c|c|}
\hline No. & Question & Answer \\
\hline 1. & $\begin{array}{c}\text { Is the instructional media easy to } \\
\text { understand? }\end{array}$ & Very easy \\
3. & $\begin{array}{c}\text { Can the media help practice? } \\
\text { Is the media evident in its } \\
\text { presentation? }\end{array}$ & Very helpful \\
4. & $\begin{array}{c}\text { Does the media make it easy to } \\
\text { practice? }\end{array}$ & Easy \\
5. & $\begin{array}{c}\text { Are the media exciting in assisting } \\
\text { the exercise? }\end{array}$ & $\begin{array}{c}\text { Interesting and fun } \\
\text { There is no }\end{array}$ \\
6. & $\begin{array}{c}\text { Are there any difficulties in } \\
\text { understanding the material in the } \\
\text { instructional media? }\end{array}$ & Can the media help increase \\
8. & $\begin{array}{c}\text { competence? } \\
\text { Can the practice questions in your } \\
\text { media put into practice? }\end{array}$ & Very helpful \\
9. & $\begin{array}{c}\text { Is the formative test easy to } \\
\text { practice? }\end{array}$ & Could \\
& $\begin{array}{c}\text { Give your comments about } \\
\text { instructional media. }\end{array}$ & Easy \\
& there is a guide in \\
\end{tabular}

The time given to study the instructional media material is sufficient so that students are elementary to answer all the questions asked in the response sheet. So the conclusion is that the small group trial results did not change much in the instructional media, both the material and the learning. The results of the tests carried out after the end of the small group trial areas in table 4 below:

Table 4. The Result Evaluate Small Group Trial

\begin{tabular}{|c|c|c|}
\hline No. & Respondent & Ability to think creatively \\
\hline 1. & Respondent-01 & Children develop very well \\
\hline 2. & Respondent-02 & Children develop as expected \\
\hline 3. & Respondent-03 & Children develop as expected \\
\hline 4. & Respondent-04 & Children develop very well \\
\hline 5. & Respondent-05 & Children develop as expected \\
\hline 6. & Respondent-06 & Children develop as expected \\
\hline
\end{tabular}

Data from the test results of small groups that all can develop very well and develop as expected. Mean that the generated media has excellent criteria can be concluded that the media is very feasible to conduct major trials or field trials. It's just that developers are still coordinating with teachers who teach in the classroom to revise learning media.

\subsection{Field Trial Results}

From input and suggestions from previous trials, field trials were carried out. Field trials aim to see the effectiveness of the instructional media in achieving predetermined learning objectives. The trial was conducted with 25 students, adjusted to the number of students who entered the 2020 academic year. The primary trial process was carried out like a small group trial; only the students' population was more than the small group trial.
Students are given instructional media and opportunities to learn. This is done because it is to identify deficiencies or weaknesses in the instructional media, be it material, instructional objectives, and learning outcomes. By the main aim of developing instructional media to increase creative thinking in early childhood. Field trials are conducting tests to see the learning training results by conducting preliminary and final examinations, likewise, with the response of students who learn using learning modules following developer teaching according to learning materials that have been done starting from the initial steps. The data descriptions on the results of the initial and final test results of the field trials can be seen in Table 5 below.

Table 5. Result Description Pre-test and Post-test

\begin{tabular}{|c|c|c|c|c|c|c|}
\hline & N & Min & Max & Mean & $\begin{array}{c}\text { Std. } \\
\text { Deviation }\end{array}$ & Variance \\
\hline Pre_Test & 25 & 2 & 4 & 3 & 0.759 & 0.577 \\
\hline Post_Test & 25 & 3 & 4 & 4 & 0.458 & 0.210 \\
\hline $\begin{array}{c}\text { Valid N } \\
\text { (listwise) }\end{array}$ & 25 & & & & & \\
\hline
\end{tabular}

Based on table 5 above, the results of the pre-test mean value of 3 stars and the products of the post-test four stars can tell that there is a change in the ability to think creatively so that the paired T-test can be carried out more clearly with the SPPS application as in table 6 below.

Table 6. Paired T results

\begin{tabular}{|c|c|c|}
\hline & $\begin{array}{c}\text { Statistical Test Results } \\
\text { Pre-Post }\end{array}$ & \\
\hline Mean & $-0,800$ & \\
\hline df & 24 & Table $=1.711$ \\
\hline T-count & 8,000 & \\
\hline Std. Deviation & 0.500 & $\alpha=0.05$ \\
\hline p-Value & 0.000 & \\
\hline
\end{tabular}

Based on table 6 above, it is found that the value of T-count $=8,000$ when compared with the t table on df 24 of 1,711. The result of paired $\mathrm{T}$ that $\mathrm{T}$ count $=8,000>1,711 \mathrm{~T}$ table can be interpreted as significant, meaning that the pre-test score is different from the post-test score. You can also look at the Sig. (2-tailed) or Paired T-test probability / p-value, 0.000 . This means: there is a difference between before and after treatment, because p-value $=0.000<\alpha=$ 0.05 (95\% confidence level). The mean value: -0.800 is negative. This means that there is a tendency to increase post-test scores after treatment. An average increase of 0.8 can be concluded that learning media effectively improves early childhood creative thinking skills in 5-6 years.

Early childhood will depend on environmental support, and strong motivation in yourself [18]. In the family, in school, there must be in the name of either creative attitudes and attitudes of group individuals in the work environment or the community[19]. Therefore, education should be the students' uniqueness and talents (do not get 
carried away with all the same things or have the same interests).

Creative thinking has several mechanisms or processes to go through[7], [19]. According to psychologists, there are five stages of creative thinking: a) Orientation; problems are formulated, and aspects of the problem are identified. b) Preparation; to collect as much information relevant to the problem as possible. c) Incubation; the process of temporary dismissal when various problems are faced with a dead end. But even so, the thought process continues in the subconscious soul. d) Illumination; when the incubation period ends with discovering a solution to solve the problem. e) Verification; stage of testing and critically assess the proposed troubleshooting in the fourth stage[20]-[23].

Indeed, the ability to think creatively basically belongs to everyone. Creative thinking is the ability to create new and original ideas. Even people who feel unable to develop new ideas can think creatively as long as they are trained. Therefore, it is necessary to know in advance how to think creatively. According to Rigolizzo and Amabille[24], there are four components of creativity, all of which contribute to the results of each person's creative process. In order, it can be stated as follows: (1) identification of problems or opportunities; (2) preparation; (3) bring up ideas; and (4) evaluation of ideas and implementation. The creative process's initial stage, namely problem identification, is solved by challenging assumptions of challenging assignments.

Creative thinking needs to be developed and nurtured in the child. According to Majesty, the child is creative, which is the child's nature and already exists. This means that they enjoy exploring the world with brilliant ideas and even using what they can find in original and original ways. Another reason for the development of creative thinking, according to Munandar[25], is as a manifestation of his embodiment. Self-realization is one of the basic needs of man. Creativity skills can be seen as a possibility to be smooth and flexible when searching for and seeing various opportunities in problem-solving from multiple perspectives that will give birth to many ideas. Creativity can also provide infinite individual satisfaction and improve individuals and societies' quality of life in the form of pictures, ...

This is supported by Orey[26], who argues that interactive media makes learning effective and learning progressive. According to research, Lewis-Pierre and Aziza[27]states that learning media facilitate learning as effective learning materials and interactive learning resources. According to Rusmono, Jarudin, and Prajka [28], digital media makes learning more accessible and effective in improving learning outcomes.

According to Mayer[29], learning is done by the teacher to achieve learning goals by facilitating students in improving education. The learning process attempts to make students learn so that a situation is a learning event, namely an attempt to change students' behaviour.[30]. Behavioural changes can occur because of the interaction between students and their environment.

Next, Gagne[31]explained that behaviour changes depend on two (2) factors, namely: factors from within and factors from outside. Meanwhile, Vogel-Walcutt[32] said that learning is an effort to provide stimulation, guidance, direction, and encouragement to students so that the learning process occurs. Digital media can motivate students to improve skills, improve performance, and performance satisfaction in digital media [33], [34]. As students increasingly need to learn content and perspectives not provided as part of the curriculum, they need to build additional support for learning through digital media[35]. Digital media learners who successfully deal with distractions in socio-cognitive conflict resolution and productive friction are indispensable for learning and knowledge construction[36], [37].

\section{Conclusions}

The development of instructional media to improve creative thinking skills by applying a systems approach tailored to special students' backgrounds and needs for early childhood, the age range of 5-6 years. Instructional media that is built through the formulation of learning objectives, identification of needs, competency maps, preparation of specific learning objectives, bragging of assessment tools, and learning strategies in the learning system depart from the assumption that a person's knowledge, skills, and attitudes can be changed through his learning experience and information processing.

Development instructional media can help children in cognitive training in a measured and directed manner. Learning materials are developed to assist the learning process in improving creative thinking skills through instructional media, carried out for 30 minutes every day for two months regularly. This instructional media is easy to use because it is equipped with a QR Code hyperlink. Students do not need to read the tutorial and use the media according to the material or level.

Teachers and parents must socialise to support instructional media use widely because this instructional media is easy to operate or use. The Instructional media product developed is a learning resource for cognitive training in improving children's creative thinking skills ages 5-6 years.

\section{REFERENCES}

[1] S. Perren, F. Sticca, B. Weiss-Hanselmann, and C. Burkhardt Bossi, "Let us play together! Can play tutoring stimulate children's social pretend play level?," J. Early Child. Res., vol. 17, no. 3, pp. 205-219, 2019, doi: $10.1177 / 1476718 X 19849248$. 
[2] E. Lee and M. J. Hannafin, "A design framework for enhancing engagement in student-centered learning: own it, learn it, and share it," Educ. Technol. Res. Dev., vol. 64, no. 4, pp. 707-734, 2016, doi: 10.1007/s11423-015-9422-5.

[3] Z. Dere, "Investigating the creativity of children in early childhood education institutions," Univers. J. Educ. Res., vol. 7, no. 3, pp. 652-658, 2019, doi: 10.13189/ujer.2019.070302.

[4] S. Amiran, "Efektifitas Penggunaan Metode Bermain Di Paud Nazareth Oesapa," J. Pendidik. Anak, vol. 5, no. 1, 2016, doi: 10.21831/jpa.v5i1.12367.

[5] M. Mirawati and E. Rahmawati, "Permainan Modifikasi Untuk Stimulasi Keterampilan Gerak Dasar Manipulatif Anak Usia 2-4 Tahun," Early Child. J. Pendidik., vol. 1, no. 2, pp. 38-50, 2017, doi: 10.35568/earlychildhood.v1i2.119.

[6] F. Samad and N. Tidore, "Strategi Pembelajaran Bahasa Inggris Yang Menyenangkan Untuk Anak Usia Dini," Cahaya PAUD, vol. 2, pp. 47-57, 2015, [Online]. Available: https://www.google.com/url?sa $=$ t\&rct=j\&q=\&esrc=s\&sourc $\mathrm{e}=$ web\&cd=1\&cad=rja\&uact $=8 \&$ ved=2ahUKEwjNsPHfpZ niAhUG3Y8KHdQ6ATEQFjAAegQIBRAC\&url=https\%3 A\%2F\%2Fejournal.unkhair.ac.id\%2Findex.php\%2Fcahayap d $\% 2$ Farticle $\% 2$ Fdownload $\% 2$ F $226 \% 2$ F $176 \&$ usg=AOvVaw 0ydqCIsvm2s-LTN4RHZ.

[7] T. Seechaliao, "Instructional Strategies to Support Creativity and Innovation in Education," J. Educ. Learn., vol. 6, no. 4, p. 201, 2017, doi: 10.5539/jel.v6n4p201.

[8] G. Walsh, P. Murphy, and et al Dunbar, C., "Thinking Skills in the Early Years: A Guide for Practitioners," North. Irel. Counc. Curriculum, Assessent Exam., 2008, [Online]. Available:

http://www.nicurriculum.org.uk/TSPC/doc/ThinkingSkillsin theEarlyYears_Report.pdf.

[9] B. V. Márquez, M. Á. C. Ontiveros, and M. O. Pons, "Innovation and creativity Electricity," Mélanges l'École française Rome. Antiq., vol. 11, no. 128-1, pp. 53-74, 2016, doi: $10.4000 /$ mefra. 3428 .

[10]D. Martin, A. Craft, and H. Tillema, "Developing Critical and Creative Thinking Strategies in Primary School Pupils: an inter-cultural study of teachers' learning," J. In-service Educ., vol. 28, no. 1, pp. 115-134, 2002, doi: $10.1080 / 13674580200200174$.

[11] C. Sharp, "Developing Young Children's Creativity Through the Arts: What Does Research Have to Offer?," Invit. Semin., vol. 2, pp. 1-21, 2019.

[12] Talibi, "Utilization of Instructional Media For Quality Training In Pre - Primary School Teacher Training," J. Educ., vol. 2, no. 7, p. 2014, 2014.

[13] P. Dube, "Utilisation of Instructional Media in Teaching and Learning by Secondary School Teachers. A Case of MKOBA 1 High School," Int. J. Innov. Sci. Res. Technol., vol. 4, no. 9, pp. 409-420, 2020, [Online]. Available: www.ijisrt.com.

[14] M. Fischer, G. \& Sugimoto, "Supporting self-directed learners and learning communities with sociotechnical environments," Res. Pract. Technol. Enhanc. Learn., vol. 1, no. 1, pp. 31-64, 2006, doi: 10.1142/S1793206806000020.

[15] M. J. Hannafin and L. L. Peck, The Design Development and Education of Instructional Software, vol. 1, no. 1. New York: Mc. Millan Publ., Co, 1998.
[16] M. D. Gall, J. P. Gall, and W. R. Borg, Educational Research: An Introduction, 9Th ed. New York: Pearson, 2016.

[17] A. Pérez et al., "Instructional Media," BMC Public Health, vol. 5, no. 1, pp. 1-8, 2017, [Online]. Available: https://ejournal.poltektegal.ac.id/index.php/siklus/article/vie w/298\%0Ahttp://repositorio.unan.edu.ni/2986/1/5624.pdf\% 0Ahttp://dx.doi.org/10.1016/j.jana.2015.10.005\%0Ahttp://w ww.biomedcentral.com/1471-2458/12/58\%0Ahttp://ovidsp. ovid.com/ovidweb.cgi?T=JS\&P.

[18] S. Moser and J. Zumbach, "Exploring the development and impact of learning styles: An empirical investigation based on explicit and implicit measures," Comput. Educ., vol. 125, pp. 146-157, 2018, doi: 10.1016/j.compedu.2018.05.003.

[19] N. Behnamnia, A. Kamsin, M. A. B. Ismail, and A. Hayati, "The effective components of creativity in digital game-based learning among young children: A case study," Child. Youth Serv. Rev., vol. 116, pp. 1-13, 2020, doi: 10.1016/j.childyouth.2020.105227.

[20] S. Amponsah, A. B. Kwesi, and A. Ernest, "Lin's creative pedagogy framework as a strategy for fostering creative learning in Ghanaian schools," Think. Ski. Creat., vol. 31, pp. 11-18, 2019, doi: 10.1016/j.tsc.2018.09.002.

[21]M. Caroselli, Activities for Developing Critical Thinking Skills. Cambridge: HRD Press, Inc, 2015.

[22] S. R. Darawsheh, B. A. Alshorman, A. M. Momani, and A. S. Al-, "The Effectiveness of a Training Program Based on Creative Thinking Skills in the Development of Self-Concept among Gifted and Outstanding Students at the Deanship of The Preparatory Year at Imam Abdul Rahman Bin Faisal University," Multicult. Educ., vol. 7, no. 1, pp. 44-55, 2021, doi: $10.5281 /$ zenodo.4411179.

[23] D. Henriksen, C. Richardson, and K. Shack, "Mindfulness and creativity: Implications for thinking and learning," Think. Ski. Creat., vol. 37, no. December 2019, pp. 1-10, 2020, doi: 10.1016/j.tsc.2020.100689.

[24] M. Rigolizzo and T. Amabile, "Entrepreneurial Creativity: The Role of Learning Processes and Work Envir- Supports," ook Creat. Innov. Entrep., pp. 1-2, 2015, doi: 10.1093/oxfordhb/9780199927678.013.0018.

[25] S. C. U. Munandar, Mengembangkan Bakat dan Kreativitas Anak Sekolah: Petunjuk bagi Para Guru dan Orang Tua. Jakarta: PT. Grasindo, 1999.

[26] M. Orey, V. J. McClendon, and R. M. Branch, Educational Media and Technology Yearbook, vol. 53, no. 9. Georgia: Springer, 2013.

[27] L. T. L. P. Pierra and K. Aziza, "Developing and implementing an interctive end-of-life education module using raptivity and ispring," Quartely Rev. Distance Educ., vol. 18, no. 1, pp. 9-15, 2017, [Online]. Available: https://eric.ed.gov/?id=EJ1152339.

[28] Rusmono, Jarudin, and P. I. Khuzaimah, "Development of Digital Instruction as a Guide in Wushu Training," Univers. $J$. Educ. Res., vol. 8, no. 3A, pp. 6-11, 2020, doi: 10.13189/ujer.2020.081402.

[29] L. Fiorella and R. E. Mayer, "What works and doesn't work with instructional video," Comput. Human Behav., vol. Volume $\quad 89$, pp. 465-470, 2018, doi: 10.1016/j.chb.2018.07.015. 
[30] I. Göksu, K. V. Özcan, R. Cakir, and Y. Göktas, "Content analysis of research trends in instructional design models: 1999-2014," J. Learn. Des., vol. 10, no. 2, p. 85, 2017, doi: 10.5204/jld.v10i2.288.

[31] R. M. Gagne, L. J. Briggs, and W. W. Wager, Principles of Instruction, Fourth Edition. United States of America: Ted Buchhlz, 2005.

[32] J. J. Vogel-Walcutt, L. Fiorella, and N. Malone, "Instructional strategies framework for military training systems," Comput. Human Behav., vol. 29, no. 4, pp. 14901498, 2013, doi: 10.1016/j.chb.2013.01.038

[33]R. Sartika, "Increasing the effectiveness of digital educational games: The effects of a learning instruction on students' learning, motivation and cognitive load," Comput. Human Behav., vol. 72, pp. 79-86, 2017, doi: 10.1016/j.chb.2017.01.040.

[34] Jarudin, N. Ibrahim, and S. Muslim, "Develop of Hyperlinks
Media to Learn Basic Wushu Techniques," Comput. Theor. Nanosci., vol. 17, no. 2/3, pp. 825-832, 2020, doi: $10.1166 /$ jctn.2019.8725.

[35] S. Ludvigsen, U. Cress, C. P. Rosé, N. Law, and G. Stahl, "Developing understanding beyond the given knowledge and new methodologies for analyses in CSCL," Int. J. Comput. Collab. Learn., pp. 359-364, 2018, doi: 10.1007/s11412-01 8-9291-0

[36] A. Bock, A. Modabber, K. Kniha, M. Lemos, N. Rafai, and F. Hölzle, "Blended learning modules for lectures on oral and maxillofacial surgery," Br. J. Oral Maxillofac. Surg., p. 6, 2018, doi: 10.1016/j.bjoms.2018.10.281.

[37] P. Holtz, J. Kimmerle, and U. Cress, "Using big data techniques for measuring productive friction in mass collaboration online environments," Int. J. Comput. Collab. Learn., pp. 439-456, 2018, doi: 10.1007/s11412-018-9285y. 